\title{
The Influence of Obesity and Different Fat Depots on Adipose Tissue Gene Expression and Protein Levels of Cell Adhesion Molecules
}

\author{
L. BOŠANSKÁ ${ }^{1}$, D. MICHALSKÝ ${ }^{2}$, Z. LACINOVÁ ${ }^{1}$, I. DOSTÁLOVÁ ${ }^{1}$, M. BÁRTLOVÁ ${ }^{1}$, \\ D. HALUZÍKOVÁ ${ }^{1,3}$, M. MATOULEK ${ }^{1}$, M. KASALICKÝ ${ }^{4}$, M. HALUZÍ́ ${ }^{1}$ \\ ${ }^{1}$ Third Department of Medicine, First Faculty of Medicine, Charles University, Prague, Czech \\ Republic, ${ }^{2}$ Department of Surgery, First Faculty of Medicine, Charles University, Prague, Czech \\ Republic, ${ }^{3}$ Department of Sports Medicine, First Faculty of Medicine, Charles University, Prague, \\ Czech Republic, ${ }^{4}$ Department of Surgery, Central Military Hospital, Prague, Czech Republic
}

Received October 23, 2008

Accepted January 28, 2009

On-line February 27, 2009

\begin{abstract}
Summary
Increased circulating adhesion molecules in patients with obesity play an important role in the development of endothelial dysfunction/atherosclerosis. The aim of this study was to assess the contribution of various fat depots to the production of adhesion molecules in obesity. 12 women with 1st and 2nd degree of obesity, 13 women with 3rd degree of obesity and 14 lean age-matched women were included into study. Circulating levels of vascular cell adhesion molecule-1 (VCAM-1), intercellular adhesion molecule-1 (ICAM-1), and E-selectin were measured by Luminex kits. mRNA expression of ICAM-1, VCAM-1, E-selectin, monocyte chemoattractant protein-1 (MCP-1), and CD68 in subcutaneous (SAT) and visceral adipose tissue (VAT) was measured by RT-PCR; ICAM- 1 and VCAM-1 protein levels by Luminex kits, normalized to protein content. Obesity increased ICAM-1 and VCAM-1 mRNA expression and protein levels and CD68 mRNA expression in VAT. Expression of E-selectin and MCP-1 did not significantly differ between groups. Expression of ICAM-1 and VCAM-1 positively correlated with expression of CD68 in both adipose depots. In VAT, ICAM- 1 and VCAM-1 expression and protein levels positively correlated with BMI. Obesity was associated with increased adhesion molecules mRNA expression and protein levels in VAT, but not in SAT. Increased adhesion molecules production in visceral fat may provide a novel direct link between visceral adiposity and increased risk of cardiovascular complications.
\end{abstract}

\section{Key words}

Adhesion molecules • Atherosclerosis • Obesity • Adipose tissue • Gene expression

\section{Corresponding author}

M. Haluzík, Third Department of Medicine, First Faculty of Medicine, Charles University, U Nemocnice 1, 12808 Prague 2, Czech Republic. E-mail: mhalu@If1.cuni.cz

\section{Introduction}

Endothelial dysfunction represents an early phase of vascular changes that eventually lead to atherosclerosis with all its unfavorable complications (Blankenberg et al. 2003, Blann 2003). Numerous studies have found that the presence of obesity in particular in combination with other metabolic abnormalities commonly referred to as metabolic or insulin resistance syndrome markedly increases the risk of atherosclerosis and its complications (Meigs 2004, Haffner 2006). Increasing evidence suggests that an ongoing subclinical inflammation is closely involved in the pathogenesis of obesity and its associated complications such as insulin resistance, dyslipidemia and atherosclerosis (Devaraj et al. 2004). In the early stages of atherosclerosis biomarkers of endothelial dysfunction, including intercellular adhesion molecule-1 (ICAM-1), vascular cell adhesion molecule-1 (VCAM-1), and E-selectin, are increased in response to subclinical inflammation and play an important role in the formation of atherosclerotic plaque (Blankenberg et al. 2003). Numerous studies documented increased circulating levels of soluble adhesion molecules in obesity (Price and Loscalzo 1999, 
Pontiroli et al. 2004), but the mechanisms are still not completely clear (Ferri et al. 1999, Pontiroli et al. 2004).

It is now generally accepted that adipose tissue secretes a variety of factors that exert important roles in the local and systemic regulation of numerous metabolic and inflammatory processes (Frayn et al. 2003, Rajala and Scherer 2003, Haluzík et al. 2004). Dysregulated endocrine function of adipose tissue, in particular in visceral compartment, triggers obesity-associated chronic low-grade inflammation (Trayhurn 2005, Murdolo and Smith 2006) and contributes to the development of obesity-related metabolic complications, including atherosclerosis (Rajala and Scherer 2003, Gable et al. 2006, Dostálová et al. 2009, Haluzík et al. 2009). Increased expression of chemokines, e.g. monocyte chemoattractant protein-1 (MCP-1) (Trayhurn 2005), and adhesion molecules, e.g. ICAM-1 (Brake et al. 2006), by adipocytes and macrophages accumulated in adipose tissue of obese subjects may participate in the development of atherosclerosis.

Although the increase in circulating levels of adhesion molecules in obesity is well documented, the contribution of subcutaneous and visceral fat depots to the circulating pool of adhesion molecules is uncertain. Here we tested the hypothesis that both subcutaneous and visceral adipose tissue contribute to the production of adhesion molecules and that this production might be increased in obese patients relative to lean control subjects. To this end, we examined mRNA expression and protein levels of ICAM-1, VCAM-1 and E-selectin in subcutaneous (SAT) and visceral adipose tissue (VAT) of obese and lean healthy women and studied the relationship of local and systemic levels of these adhesion molecules with anthropometric, hormonal and biochemical parameters.

\section{Patients and Methods}

\section{Study subjects}

Twenty-five obese women and fourteen normalweight age-matched control women $(\mathrm{C}$; body mass index (BMI): $23.8 \pm 0.6 \mathrm{~kg} / \mathrm{m}^{2}$ ) were included in the study. Obese women were divided into two subgroups: women with BMI 30-40 kg/m² (obese group 1; BMI: $35.7 \pm 0.9$ $\mathrm{kg} / \mathrm{m}^{2}$ ) and BMI $>40 \mathrm{~kg} / \mathrm{m}^{2}$ (obese group 2; BMI: $\left.46.2 \pm 0.8 \mathrm{~kg} / \mathrm{m}^{2}\right)$. In obese group 1 , six patients had elevated fasting plasma glucose levels $(5.6-7.0 \mathrm{mmol} / \mathrm{l})$ at the time of examination, one patient had type 2 diabetes mellitus treated by diet. In obese group 2 , two patients had elevated fasting plasma glucose levels and four patients had type 2 diabetes mellitus treated by diet or peroral antidiabetics. Eight patients of each obese group were taking antihypertensive medication. Two obese subjects were treated with statins. At the time of examination blood pressure of all patients was within the normal range $(\leq 140 / 90 \mathrm{~mm} \mathrm{Hg})$. Control subjects had normal fasting plasma glucose levels and no history of diabetes. All patients were examined while hospitalized at the General University Hospital, Prague. The subcutaneous adipose tissue (SAT) and visceral adipose tissue (VAT) samples were obtained from the abdominal region during gastric banding surgery in obese patients and elective cholecystectomy in control women. Body weight of studied patients remained stable for at least three months prior the study. Patients with coronary heart disease, stroke, renal or liver failure or acute infection were excluded from the study. Written informed consent was signed by all participants before being enrolled in the study. The study was approved by the Human Ethical Review Committee, First Faculty of Medicine and General University Hospital, Prague, Czech Republic, and was performed in accordance with the guidelines proposed in the Declaration of Helsinki.

Anthropometric examination, blood sampling and adipose tissue sampling

Anthropometric examination of all subjects was performed one day before surgery. Blood samples for biochemical and hormonal measurements were withdrawn between 07:00 and 08:00 h after an overnight fasting at basal state (at the day of operation before the start of anesthesia). Serum samples were stored in aliquots at $-70{ }^{\circ} \mathrm{C}$ until further analysis.

Samples of SAT and VAT for mRNA expression analysis were obtained from abdominal region at the beginning of surgery, from the tissue that has not been previously traumatized mechanically or by cauterization to avoid the influence of local tissue damage on studied parameters. The tissue samples were collected to RNA stabilization reagent (RNAlater, Qiagen, Germany) and stored at $-70{ }^{\circ} \mathrm{C}$ until further processing.

\section{Hormonal and biochemical assays}

Serum concentrations of soluble E-selectin, ICAM-1 and VCAM-1 were measured using Human CardiovascularDisease LINCOplex Kit on Luminex ${ }^{\circledR} 200$ instrument (Linco Research, USA). Sensitivity was $79 \mathrm{pg} / \mathrm{ml}$ for E-selectin, $16 \mathrm{pg} / \mathrm{ml}$ for VCAM-1, $9 \mathrm{pg} / \mathrm{ml}$ 
for ICAM-1; intra- and interassay variability $<12.0 \%$ and $16.0 \%$, respectively. Serum insulin concentrations were measured by commercial RIA kit (CisBioInternational, France), C-reactive protein (CRP) levels by UltraSensitive CRP ELISA kit (Diagnostic Systems Laboratories, Inc., USA). Biochemical parameters were measured in the Department of Biochemistry of General University Hospital by standard laboratory methods.

HOMA-R (homeostasis model assessment of insulin resistance) index was calculated as previously described (Matthews et al. 1985).

\section{Determination of $m R N A$ expression and protein levels}

Total RNA was extracted from $60-100 \mathrm{mg}$ of subcutaneous and visceral adipose tissue by homogenization and isolation, as described previously (Lacinova et al. 2008). Concentration and purity of RNA were determined by spectrophotometer (BioPhotometr Eppendorf AG, Hamburg, Germany). The integrity of the RNA was checked by visualization of $18 \mathrm{~S}$ and $28 \mathrm{~S}$ ribosomal bands on $1 \%$ agarose gel with an ethidium bromide.

0.1-1 $\mu \mathrm{g}$ of total RNA was used for reverse transcription to synthesize the first strand cDNA, further used for determination of gene expression of E-selectin, ICAM-1, VCAM-1, MCP-1 and CD68 (monocyte/ macrophage marker), and 18S RNA by RT-PCR using TaqMan ${ }^{\circledR}$ Universal PCR MasterMix, NO AmpErase ${ }^{\circledR}$ UNG and specific TaqMan Gene expression Assays (Applied Biosystems, Foster City, CA).

All PCRs for each gene were amplified separately. Controls with no template cDNA were performed with each assay and all samples were run at least in duplicates. The increase in fluorescence was measured in real time and data were obtained as treshold cycle $\left(\mathrm{C}_{\mathrm{T}}\right)$ values. Results were normalized to $18 \mathrm{~S}$ RNA. Relative gene expression was calculated using the

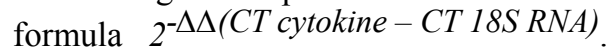

Approximately 100-200 mg adipose tissue (SAT and VAT) from each subject was homogenized in $250 \mu \mathrm{l}$ of ice-cold homogenization buffer. The homogenate was centrifuged at $3,000 \times \mathrm{g}$ for $15 \mathrm{~min}$ at $4{ }^{\circ} \mathrm{C}$, the fat cake was discarded and the homogenate was centrifuged again at $14,000 \times \mathrm{g}$ for $20 \mathrm{~min}$ at $4{ }^{\circ} \mathrm{C}$. The supernatant was stored in aliquots at $-70{ }^{\circ} \mathrm{C}$. ICAM-1 and VCAM-1 protein levels in adipose tissue homogenates were measured using HumanCardiovascular LINCOplex Kit on Luminex ${ }^{\circledR} 200$ instrument (Linco Research, USA) and normalized to protein content $(1 \mathrm{mg})$. Total protein concentration of each sample was estimated by the BioRad Laboratories, Inc., protein dye reagent according to the manufacturer's protocol (Hercules, CA, USA).

\section{Statistical analysis}

The statistical analysis was performed on SigmaStat software (SPSS Inc., Chicago). Results are expressed as means \pm S.E.M. Differences of gene expression and serum parameters between obese and nonobese were evaluated using unpaired $t$-test, MannWhitney Rank Sum Test or One-Way ANOVA, as appropriate. The relationships between the data were calculated by Pearson or Spearman correlation test. Statistical significance was assigned to $\mathrm{p}<0.05$.

\section{Results}

\section{Patients' characteristics}

Anthropometric, biochemical and hormonal characteristics of the subjects are summarized in Table 1. The groups studied were age-matched. Both obese subgroups had markedly increased BMI, CRP levels, HOMA index, blood glucose and insulin levels, and significantly reduced HDL-cholesterol relative to control group (C). Glycated hemoglobin levels, LDL-cholesterol levels, systolic and diastolic blood pressure did not significantly differ between $\mathrm{C}$ and obese subgroups. Total cholesterol levels were significantly reduced in obese group $2\left(\mathrm{BMI}>40 \mathrm{~kg} / \mathrm{m}^{2}\right)$ in comparison to $\mathrm{C}$ group. Serum triglycerides levels were significantly increased in obese group 1, but not in obese group 2, reative to controls.

\section{Serum concentrations of soluble adhesion molecules}

Serum concentration of E-selectin and ICAM-1 were significantly increased in obese group 2 in comparison to control women. Soluble VCAM-1 levels did not differ among the groups studied (Table 1).

mRNA expression and protein levels of adhesion molecules in subcutaneous and visceral adipose tissue

In SAT, mRNA expression of E-selectin, ICAM1 and VCAM-1 did not significantly differ between obese and lean women (Figs 2A, 2B and 2C). Similarly, no significant differences in ICAM-1 and VCAM-1 protein levels were found in SAT (Figs 1A and 1B).

In VAT, mRNA expression and protein levels of ICAM-1 and VCAM-1 were significantly increased in both obese groups relative to $\mathrm{C}$ group. mRNA expression 
Table 1. Anthropometric, hormonal, and biochemical characteristics of the obese patients and healthy control women.

\begin{tabular}{|c|c|c|c|}
\hline & $\begin{array}{l}\text { Control group } \\
(n=14)\end{array}$ & $\begin{array}{l}\text { Obese group } 1 \\
\text { BMI 30-40 }(n=12)\end{array}$ & $\begin{array}{l}\text { Obese group } 2 \\
\text { BMI>40 }(n=13)\end{array}$ \\
\hline Age (years) & $49.9 \pm 2.9$ & $48.7 \pm 2.4$ & $43.5 \pm 2.3$ \\
\hline$B M I\left(\mathrm{~kg} / \mathrm{m}^{2}\right)$ & $23.8 \pm 0.6$ & $35.7 \pm 0.9 * *$ & $46.2 \pm 0.8 * * \circ \circ$ \\
\hline C-reactive protein (mg/l) & $3.0 \pm 0.7$ & $23.3 \pm 6.3 *$ & $20.2 \pm 3.4 * *$ \\
\hline Blood glucose (mmol/l) & $4.1 \pm 0.25$ & $5.6 \pm 0.2 * *$ & $6.6 \pm 0.9 *$ \\
\hline Glycated hemoglobin HbAlc (\%) (IFCC) & $3.8 \pm 0.06$ & $3.8 \pm 0.15$ & $4.7 \pm 0.4$ \\
\hline Total cholesterol $(\mathrm{mmol} / \mathrm{l})$ & $5.1 \pm 0.3$ & $4.7 \pm 0.15$ & $4.4 \pm 0.2 *$ \\
\hline LDL-cholesterol (mmol/l) & $3.4 \pm 0.2$ & $2.9 \pm 0.16$ & $2.8 \pm 0.2$ \\
\hline Triglycerides $(\mathrm{mmol} / \mathrm{l})$ & $1.1 \pm 0.15$ & $1.8 \pm 0.2 *$ & $1.5 \pm 0.14$ \\
\hline HDL-cholesterol (mmol/l) & $1.2 \pm 0.06$ & $0.9 \pm 0.05 * *$ & $0.9 \pm 0.08 *$ \\
\hline Insulin (mIU/l) & $8.6 \pm 1.2$ & $20.8 \pm 3.5 *$ & $21.6 \pm 5.9 *$ \\
\hline HOMA index & $1.4 \pm 0.2$ & $4.7 \pm 1.2 *$ & $4.9 \pm 1.4 *$ \\
\hline Systolic blood pressure (mmHg) & $121 \pm 3.5$ & $129 \pm 3.6$ & $130 \pm 4.4$ \\
\hline Diastolic blood pressure $(\mathrm{mmHg})$ & $74 \pm 2.4$ & $82 \pm 2.2$ & $82 \pm 3.6$ \\
\hline Soluble E-selectin $(\mathrm{ng} / \mathrm{ml})$ & $14.7 \pm 1.4$ & $16.4 \pm 1.7$ & $25.1 \pm 3.2 *$ \\
\hline Soluble ICAM-1 (ng/ml) & $147.1 \pm 9.5$ & $155.1 \pm 10.9$ & $194.4 \pm 17.6 *$ \\
\hline Soluble VCAM-1 (ng/ml) & $891.2 \pm 78.2$ & $908.1 \pm 36.3$ & $965.5 \pm 70.3$ \\
\hline
\end{tabular}

BMI = body mass index; HOMA = homeostasis model assessment of insulin resistance; ICAM-1 = intercellular adhesion molecule- 1 ; VCAM-1 = vascular cell adhesion molecule- $1 ; * p<0.05$ resp. ${ }^{* *} p<0.001$ vs. Control group; ${ }^{\circ} p<0.001$ Obese group 2 $\left(\right.$ BMI $>40 \mathrm{~kg} / \mathrm{m}^{2}$ ) vs. Obese group 1 (BMI $30-40 \mathrm{~kg} / \mathrm{m}^{2}$ ).

of E-selectin in VAT tended to be higher in both obese subgroups, but did not reach the statistical significance (Figs 1 and 2).

Expression of CD68 was significantly increased in VAT, but unchanged in SAT, of both obese subgroups relative to $\mathrm{C}$ group (Fig. 3A). Expression of MCP-1 did not significantly differ between groups in any fat depot (Fig. 3B).

The relationship of adhesion molecules with other studied anthropometric, hormonal, and biochemical parameters

The relationship of studied adhesion molecules with other parameters was calculated in a combined population of all three groups. Serum soluble E-selectin concentration positively correlated with BMI, glucose levels, HOMA index, VCAM-1 and ICAM-1 levels, and systolic blood pressure. Soluble ICAM-1 concentration positively correlated with glycated hemoglobin levels, systolic blood pressure and soluble VCAM-1 levels. Serum soluble VCAM-1 concentration positively correlated with HDL-cholesterol levels (data not shown).

In SAT, protein levels of ICAM-1 significantly positively correlated with its circulating levels. SAT expression of ICAM-1 and VCAM-1 significantly positively correlated with CD68 mRNA expression. Expression of VCAM-1 and E-selectin in SAT significantly positively correlated with serum insulin levels (Table 2).

In VAT, mRNA expression as well as protein levels of ICAM-1 and VCAM-1 significantly positively correlated with BMI. Expression of VCAM-1, ICAM-1, and E-selectin significantly positively correlated with expression of CD68 in VAT. mRNA expression of E-selectin and ICAM-1 in VAT positively correlated with glycated hemoglobin and MCP-1 expression in VAT. Protein levels of ICAM-1 in VAT significantly positively correlated with triglyceride and glucose levels. mRNA expression of CD68 positively correlated with BMI in both SAT and VAT (Table 2).

\section{Discussion}

The most important finding of this study are the differences in mRNA and protein abundance of adhesion molecules in adipose tissue of obese and lean women. The expression and protein levels of ICAM-1 and VCAM-1 were significantly higher in VAT, but not in $\mathrm{SAT}$, of obese women relative to lean women, whereas 
ICAM-1 protein
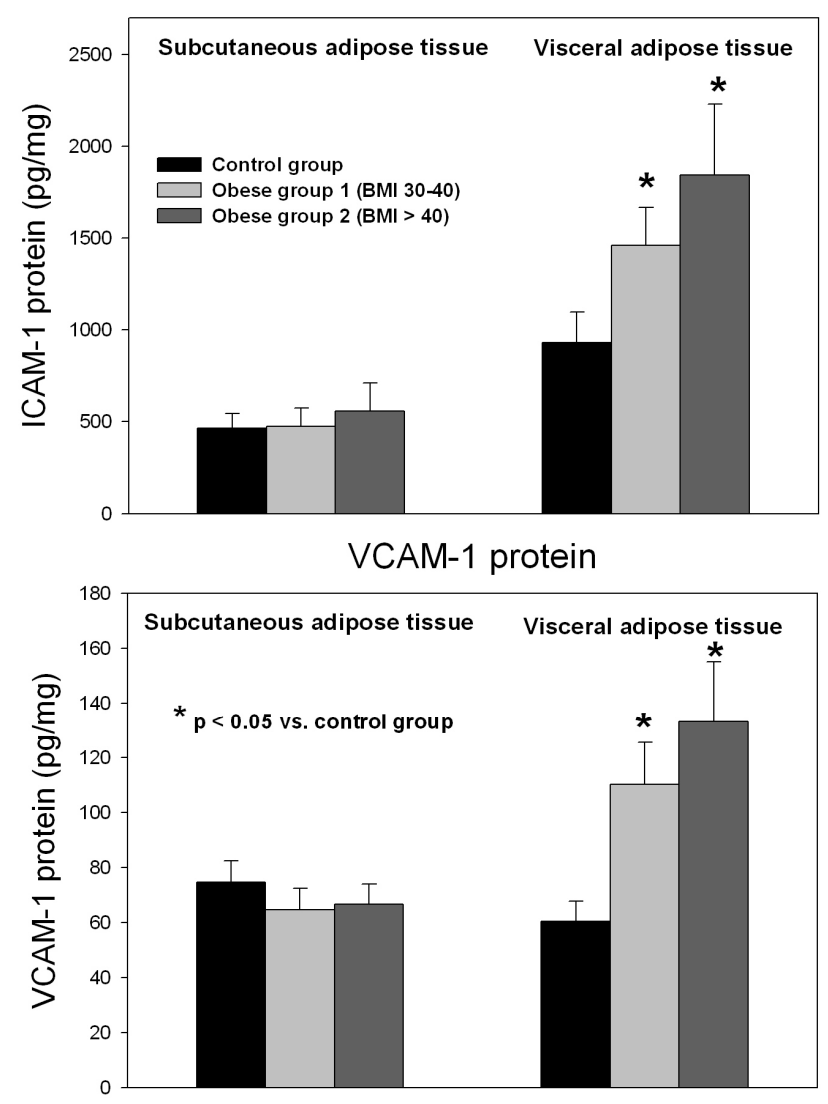

Fig. 1A,B. Protein levels of intercellular adhesion molecule-1 (ICAM-1) (A) and vascular cell adhesion molecule (VCAM-1) (B) in subcutaneous and visceral adipose tissue of control lean women $(n=14)$, obese group 1 (BMI $\left.30-40 \mathrm{~kg} / \mathrm{m}^{2} ; n=12\right)$ and obese group 2 (BMI $\left.>40 \mathrm{~kg} / \mathrm{m}^{2} ; \mathrm{n}=13\right)$.

the expression of E-selectin and MCP-1 did not significantly differ between the groups studied in any adipose depot. mRNA expression of ICAM-1 and VCAM-1 in VAT was significantly related to the expression of macrophage-related marker CD68 and to BMI.

Circulating levels of soluble adhesion molecules are markers of endothelial activation (Pigott et al. 1992, Bošanská et al. 2008), being elevated in obese individuals in majority (Ferri et al. 1999, Pontiroli et al. 2004), but not all (Matsumoto et al. 2002) previously published studies. Here we found significantly increased levels of soluble E-selectin and ICAM-1, but not VCAM-1, in obese women with $\mathrm{BMI}>40 \mathrm{~kg} / \mathrm{m}^{2}$ relative to lean controls. The lack of difference in circulating adhesion molecules between obese women with BMI 30-40 kg/m² and lean women may be partially explained by their lower BMI value as compared with obese group 2 (Ferri et al. 1999, Troseid et al. 2005), possibly also by antihypertensive medication of obese subjects (Boulbou
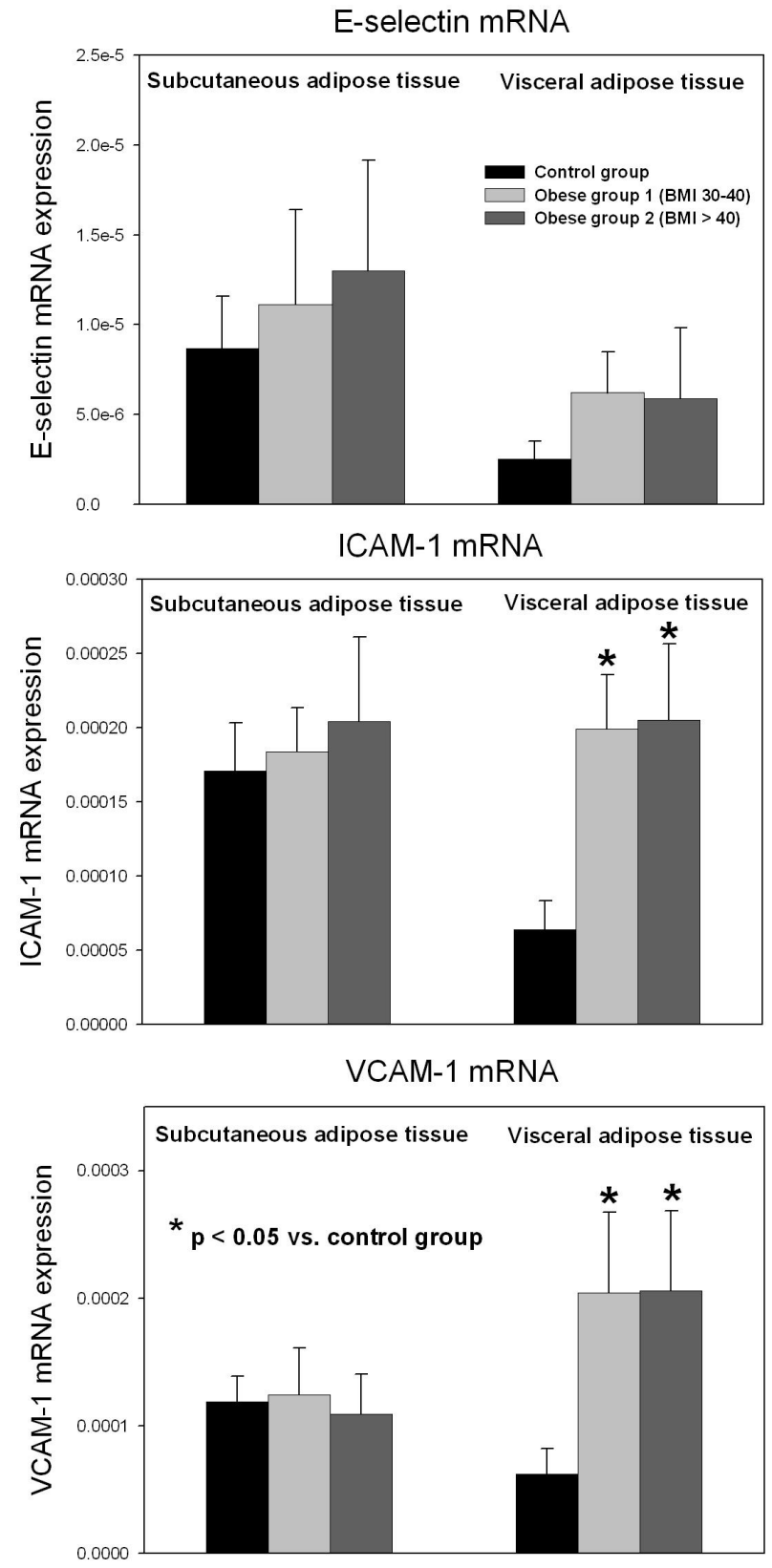

Fig. 2A,B,C. mRNA expression of E-selectin (A), intercellular adhesion molecule-1 (ICAM-1) (B) and vascular cell adhesion molecule (VCAM-1) (C) in subcutaneous and visceral adipose tissue of control lean women $(n=14)$, obese group 1 (BMI 30$\left.40 \mathrm{~kg} / \mathrm{m}^{2} ; \mathrm{n}=12\right)$ and obese group $2\left(\mathrm{BMI}>40 \mathrm{~kg} / \mathrm{m}^{2} ; \mathrm{n}=13\right)$.

et al. 2005) or estrogen influence due to differences in pre- and postmenopausal status (Oger et al. 2001, Hemelaar et al. 2005, Shifren et al. 2008).

We confirmed previous findings (Tsakadze et al. 2004) that adhesion molecules are expressed in human adipose tissue which may thus be a potential source of circulating adhesion molecules in obesity. Although we found a significant relationship only between ICAM-1 protein levels in SAT and its circulating levels, accumulating evidence from previous studies suggests 

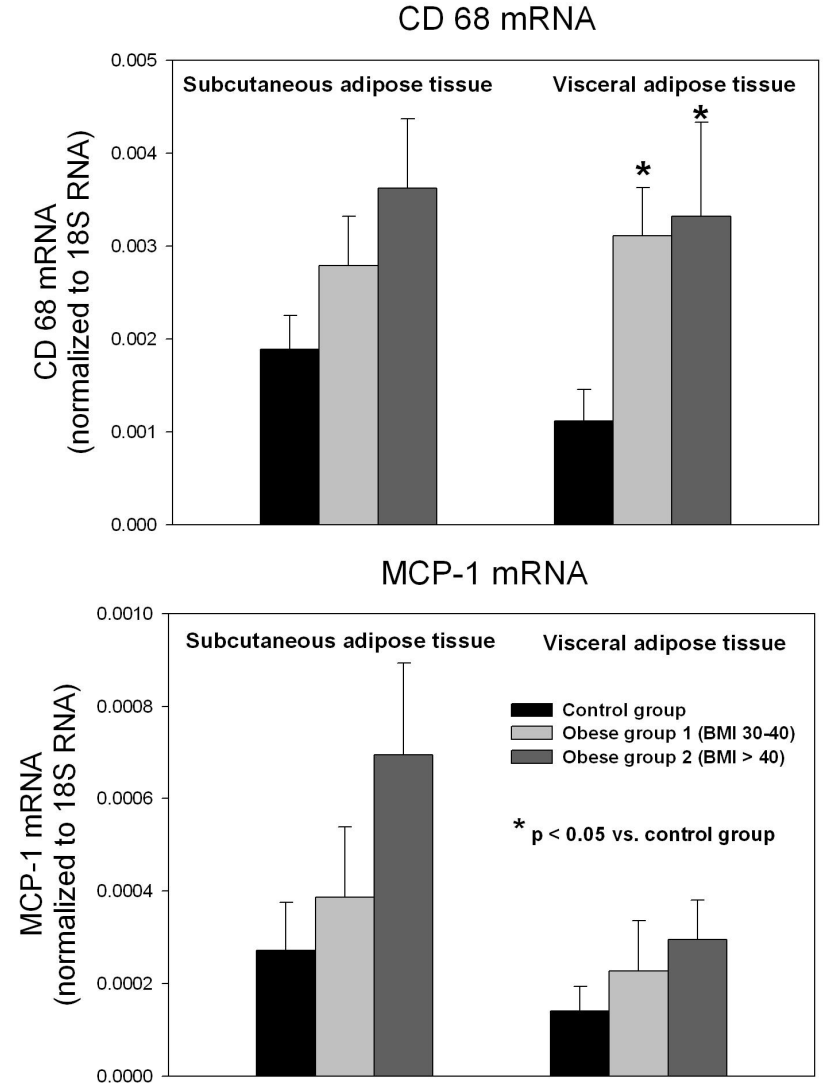

Fig. 3A,B. mRNA expression of CD68 and monocyte chemoattractant protein-1 (MCP-1) in subcutaneous and visceral adipose tissue of control lean women $(n=14)$, obese group 1 (BMI $\left.30-40 \mathrm{~kg} / \mathrm{m}^{2} ; \mathrm{n}=12\right)$ and obese group $2\left(\mathrm{BMI}>40 \mathrm{~kg} / \mathrm{m}^{2}\right.$; $n=13)$.

that circulating levels of adhesion molecules reflect the combination of their production by endothelial or immunocompetent cells outside the adipose tissue and by various cells within the adipose tissue (Blankenberg et al. 2003, Brake et al. 2006, Sengenes et al. 2007). Furthermore, individual adhesion molecules could have specific roles in the adhesion pathway and specific predominant sources and mode of expression (Blankenberg et al. 2003, Marchesi et al. 2007).

One of possible roles of adhesion molecules production in adipose tissue may lie in the paracrine regulation of local inflammatory processes rather than in their systemic effects. Adhesion molecules in adipose tissue may contribute to the recruitment and activation of macrophages in obesity (Brake et al. 2006). Significant association of adhesion molecules expression in VAT with BMI and CD68 could partially explain the association of visceral obesity and macrophage infiltration in adipose tissue with endothelial dysfunction. Endothelial dysfunction in the capillary and arteriolar tissue microcirculation is one of the key steps in the evolution of tissue insulin resistance (Serne et al. 2002). The increase in ICAM-1 and VCAM-1 expression in VAT may thus be linked to the development of type 2 diabetes and atherosclerosis, which are increasingly linked to chronic inflammation. Our results further underline the possible role of VAT in numerous pathophysiological processes related to obesity and provide a novel direct link to explain the mechanism of association of abdominal obesity with cardiovascular diseases (Eckel and Krauss 1998).

We have previously shown that in contrast to VAT, the expression of adhesion molecules in SAT was regulated differently (Bošanská et al. 2008) and was decreased in obese in comparison to lean women. Dietinduced weight reduction led to a significant increase of ICAM-1 and VCAM-1 mRNA expression in SAT. Overall, our data do not confirm the direct role of SAT adhesion molecules production in the development of endothelial dysfunction in obese patients. However, we cannot exclude that the negative results with respect to differences in adhesion molecules production in SAT were affected by relatively low number of patients included.

Although MCP-1 is a potent chemoattractant for monocytes and a marker of the inflammatory activity in patients at risk for atherosclerotic disease (Martinovic et al. 2005), we did not find any significant differences in mRNA expression of MCP-1 between obese and lean subjects in any adipose tissue depot. This finding may indicate that other factors than MCP-1 (i.e. adhesion molecules themselves) could play a crucial role in monocyte infiltration of adipose tissue in obese patients.

Previously published studies have shown a direct connection between CD68 mRNA abundance and higher counts of infiltrating macrophages in the adipose tissue of obese subjects (Harman-Boehm et al. 2007, Apovian et al. 2008). Reports on proportional increase of CD68 in humans with adiposity (Weisberg et al. 2003) are in agreement with the direct relationship of CD68 with BMI found in our study. Recently, macrophages have been found to be a major source of platelet-derived growth factor in adipose tissue, the factor induced by local hypoxia that may thus stimulate angiogenesis in adipose tissue (Pang et al. 2008). Moreover, in the state of positive energy balance, activated endothelial cells as well as growing fat cells may produce factors that directly or indirectly induce angiogenesis, as more intense vascularization is needed, e.g. for maintaining chronic inflammatory state (Arner 2007, Sengenes et al. 2007). 


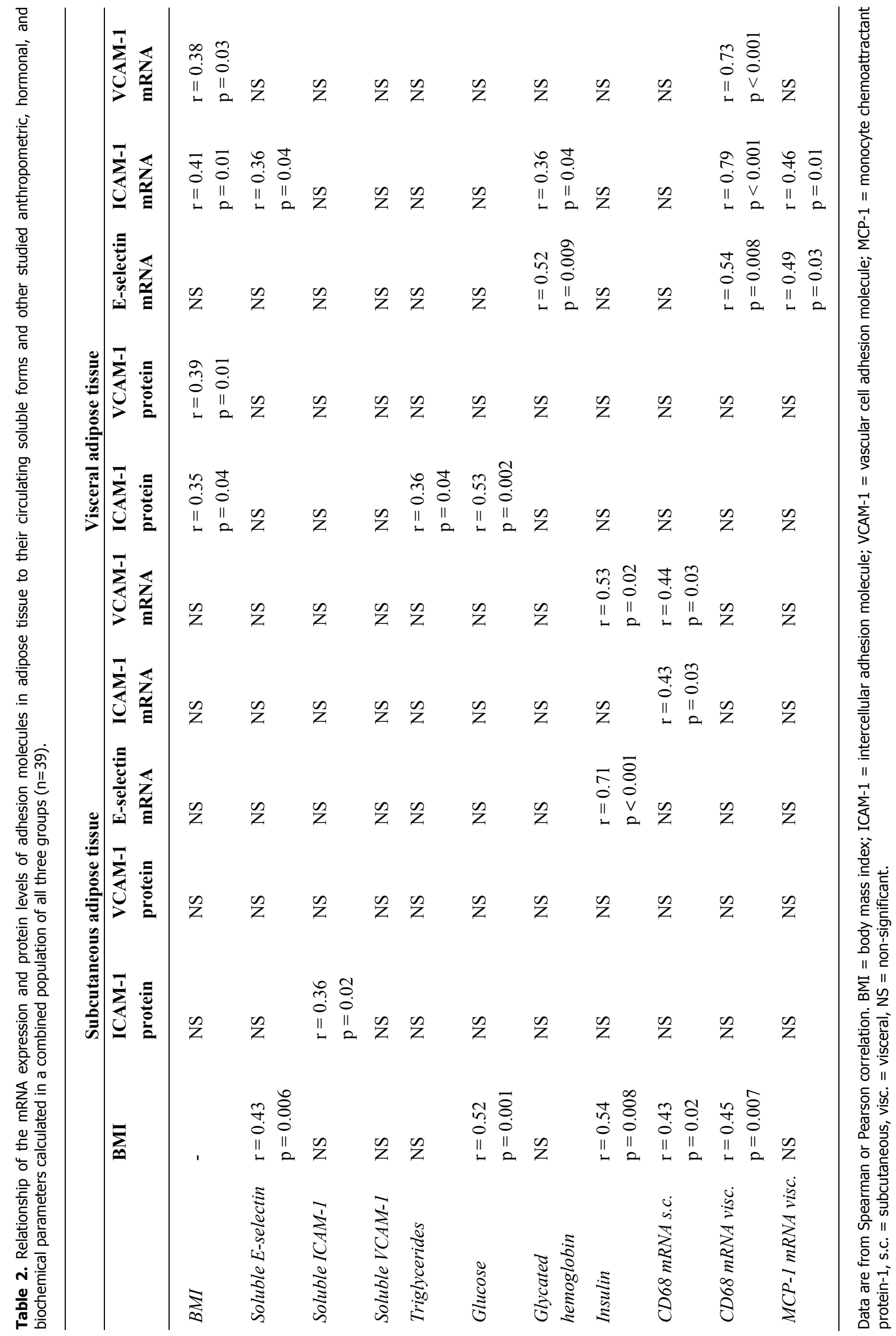


However, the role of the macrophage infiltration is still not fully understood. The question remains whether adipocytes or immunocompetent cells residing in adipose tissue are the main sources of increased production of adhesion molecules in VAT of obese subjects. We have previously shown that both isolated adipocytes and stroma-vascular fraction produce adhesion molecules (Dolínková et al. 2008). Expression of VCAM-1 was five times lower in visceral adipocytes than in whole VAT, whereas expression of E-selectin was eight times higher in visceral adipocytes than in whole VAT in obese patients (Dolínková et al. 2008). Therefore, enhanced release of some adhesion molecules (e.g. VCAM-1) in VAT as compared with SAT could be due to its production by both non-adipose cells such as macrophages or other immunocompetent cells, and adipocytes (Fain et al. 2007).
We conclude that obesity is associated with increased mRNA expression and protein levels of adhesion molecules, including ICAM-1 and VCAM-1, in VAT, but not in SAT. The expression of adhesion molecules in VAT of obese patients is strongly related to BMI and the degree of tissue infiltration by macrophages. Increased adhesion molecules production in visceral fat may provide a novel direct link between visceral adiposity and increased risk of cardiovascular complications.

\section{Conflict of Interest}

There is no conflict of interest.

\section{Acknowledgements}

Supported by IGA8302-5 and MZ0VFN2005.

\section{References}

APOVIAN CM, BIGORNIA S, MOTT M, MEYERS MR, ULLOOR J, GAGUA M, MCDONNELL M, HESS D, JOSEPH L, GOKCE N: Adipose macrophage infiltration is associated with insulin resistance and vascular endothelial dysfunction in obese subjects. Arterioscler Thromb Vasc Biol 28: 1654-1659, 2008.

ARNER P: Introduction: the inflammation orchestra in adipose tissue. J Intern Med 262: 404-407, 2007.

BLANKENBERG S, BARBAUX S, TIRET L: Adhesion molecules and atherosclerosis. Atherosclerosis 170: 191-203, 2003.

BLANN AD: Assessment of endothelial dysfunction: focus on atherothrombotic disease. Pathophysiol Haemost Thromb 33: 256-261, 2003.

BOŠANSKÁ L, LACINOVÁ Z, ROUBÍČEK T, MRÁZ M, BÁRTLOVÁ M, DOLEŽALOVÁ R, HOUSOVÁ J, KŘEMEN J, HALUZÍKOVÁ D, MATOULEK M, HALUZÍK M: [The influence of very-low-calorie diet on soluble adhesion molecules and their gene expression in adipose tissue of obese women]. in Czech Cas Lek Cesk 147: 32-37, 2008.

BOULBOU MS, KOUKOULIS GN, MAKRI ED, PETINAKI EA, GOURGOULIANIS KI, GERMENIS AE: Circulating adhesion molecules levels in type 2 diabetes mellitus and hypertension. Int J Cardiol 98: 39-44, 2005.

BRAKE DK, SMITH EO, MERSMANN H, SMITH CW, ROBKER RL: ICAM-1 expression in adipose tissue: effects of diet-induced obesity in mice. Am J Physiol 291: C1232-C1239, 2006.

DEVARAJ S, ROSENSON RS, JIALAL I: Metabolic syndrome: an appraisal of the pro-inflammatory and procoagulant status. Endocrinol Metab Clin North Am 33: 431-453, 2004.

DOLÍNKOVÁ M, DOSTÁLOVÁ I, LACINOVÁ Z, MICHALSKÝ D, HALUZÍKOVÁ D, MRÁZ M, KASALICKÝ M, HALUZÍK M: The endocrine profile of subcutaneous and visceral adipose tissue of obese patients. Mol Cell Endocrinol 291: 63-70, 2008.

DOSTÁLOVÁ I, HALUZÍKOVÁ D, HALUZÍK M: Fibroblast growth factor 21: a novel metabolic regulator with potential therapeutic properties in obesity/type 2 diabetes mellitus. Physiol Res 58: 1-7, 2009.

ECKEL RH, KRAUSS RM: American Heart Association call to action: obesity as a major risk factor for coronary heart disease. AHA Nutrition Committee. Circulation 97: 2099-2100, 1998.

FAIN JN, NESBIT AS, SUDLOW FF, CHEEMA P, PEEPLES JM, MADAN AK, TICHANSKY DS: Release in vitro of adipsin, vascular cell adhesion molecule 1, angiotensin 1-converting enzyme, and soluble tumor necrosis factor receptor 2 by human omental adipose tissue as well as by the nonfat cells and adipocytes. Metabolism 56: 1583$1590,2007$. 
FERRI C, DESIDERI G, VALENTI M, BELLINI C, PASIN M, SANTUCCI A, DE MATTIA G: Early upregulation of endothelial adhesion molecules in obese hypertensive men. Hypertension 34: 568-573, 1999.

FRAYN KN, KARPE F, FIELDING BA, MACDONALD IA, COPPACK SW: Integrative physiology of human adipose tissue. Int J Obes Relat Metab Disord 27: 875-888, 2003.

GABLE DR, HUREL SJ, HUMPHRIES SE: Adiponectin and its gene variants as risk factors for insulin resistance, the metabolic syndrome and cardiovascular disease. Atherosclerosis 188: 231-244, 2006.

HAFFNER SM: Relationship of metabolic risk factors and development of cardiovascular disease and diabetes. Obesity (Silver Spring) 14: S121-S127, 2006.

HALUZÍK M, PAŘIIZKOVÁ J, HALUZÍK MM: Adiponectin and its role in the obesity-induced insulin resistance and related complications. Physiol Res 53: 123-129, 2004.

HALUZÍK MM, ANDERLOVÁ K, DOLEŽALOVÁ R, ADAMÍKOVÁ A, HALUZÍKOVÁ D, HOUSOVÁ J, SVAČINA S̆, HALUZÍK M: Serum adipocyte fatty acid binding protein levels in patients with type 2 diabetes mellitus and obesity: the influence of fenofibrate treatment. Physiol Res 58: 93-99, 2009.

HARMAN-BOEHM I, BLUHER M, REDEL H, SION-VARDY N, OVADIA S, AVINOACH E, SHAI I, KLOTING N, STUMVOLL M, BASHAN N, RUDICH A: Macrophage infiltration into omental versus subcutaneous fat across different populations: effect of regional adiposity and the comorbidities of obesity. J Clin Endocrinol Metab 92: 2240-2247, 2007.

HEMELAAR M, VAN DER MOOREN MJ, VAN BAAL WM, SCHALKWIJK CG, KENEMANS P, STEHOUWER CD: Effects of transdermal and oral postmenopausal hormone therapy on vascular function: a randomized, placebocontrolled study in healthy postmenopausal women. Menopause 12: 526-535, 2005.

LACINOVA Z, DOLINKOVA M, HALUZIKOVA D, KRAJICKOVA J, HALUZIK M: Comparison of manual and automatic (MagNA Pure) isolation methods of total RNA from adipose tissue. Mol Biotechnol 38: 195-201, 2008.

MARCHESI S, VAUDO G, LUPATTELLI G, LOMBARDINI R, ROSCINI AR, BROZZETTI M, SIEPI D, MANNARINO E: Fat distribution and endothelial function in normal-overweight menopausal women. $J$ Clin Pharm Ther 32: 477-482, 2007.

MARTINOVIC I, ABEGUNEWARDENE N, SEUL M, VOSSELER M, HORSTICK G, BUERKE M, DARIUS H, LINDEMANN S: Elevated monocyte chemoattractant protein-1 serum levels in patients at risk for coronary artery disease. Circ J 69: 1484-1489, 2005.

MATSUMOTO K, SERA Y, ABE Y, TOMINAGA T, HORIKAMI K, HIRAO K, UEKI Y, MIYAKE S: High serum concentrations of soluble E-selectin correlate with obesity but not fat distribution in patients with type 2 diabetes mellitus. Metabolism 51: 932-934, 2002.

MATTHEWS DR, HOSKER JP, RUDENSKI AS, NAYLOR BA, TREACHER DF, TURNER RC: Homeostasis model assessment: insulin resistance and beta-cell function from fasting plasma glucose and insulin concentrations in man. Diabetologia 28: 412-419, 1985.

MEIGS JB: Metabolic syndrome: in search of a clinical role. Diabetes Care 27: 2761-2763, 2004.

MURDOLO G, SMITH U: The dysregulated adipose tissue: a connecting link between insulin resistance, type 2 diabetes mellitus and atherosclerosis. Nutr Metab Cardiovasc Dis 16: S35-S38, 2006.

OGER E, ALHENC-GELAS M, PLU-BUREAU G, MENNEN L, CAMBILLAU M, GUIZE L, PUJOL Y, SCARABIN P: Association of circulating cellular adhesion molecules with menopausal status and hormone replacement therapy. Time-dependent change in transdermal, but not oral estrogen users. Thromb Res 101: 35-43, 2001.

PANG C, GAO Z, YIN J, ZHANG J, JIA W, YE J: Macrophage infiltration into adipose tissue may promote angiogenesis for adipose tissue remodeling in obesity. Am J Physiol 295: E313-E322, 2008.

PIGOTT R, DILLON LP, HEMINGWAY IH, GEARING AJ: Soluble forms of E-selectin, ICAM-1 and VCAM-1 are present in the supernatants of cytokine activated cultured endothelial cells. Biochem Biophys Res Commun 187: 584-589, 1992.

PONTIROLI AE, PIZZOCRI P, KOPRIVEC D, VEDANI P, MARCHI M, ARCELLONI C, PARONI R, ESPOSITO K, GIUGLIANO D: Body weight and glucose metabolism have a different effect on circulating levels of ICAM-1, E-selectin, and endothelin-1 in humans. Eur J Endocrinol 150: 195-200, 2004.

PRICE DT, LOSCALZO J: Cellular adhesion molecules and atherogenesis. Am J Med 107: 85-97, 1999. 
RAJALA MW, SCHERER PE: The adipocyte - at the crossroads of energy homeostasis, inflammation, and atherosclerosis. Endocrinology 144: 3765-3773, 2003.

SENGENES C, MIRANVILLE A, LOLMEDE K, CURAT CA, BOULOUMIE A: The role of endothelial cells in inflamed adipose tissue. J Intern Med 262: 415-421, 2007.

SERNE EH, RG IJ, GANS RO, NIJVELDT R, DE VRIES G, EVERTZ R, DONKER AJ, STEHOUWER CD: Direct evidence for insulin-induced capillary recruitment in skin of healthy subjects during physiological hyperinsulinemia. Diabetes 51: 1515-1522, 2002.

SHIFREN JL, RIFAI N, DESINDES S, MCILWAIN M, DOROS G, MAZER NA: A comparison of the short-term effects of oral conjugated equine estrogens versus transdermal estradiol on C-reactive protein, other serum markers of inflammation, and other hepatic proteins in naturally menopausal women. J Clin Endocrinol Metab 93: 1702$1710,2008$.

TRAYHURN P: Adipose tissue in obesity - an inflammatory issue. Endocrinology 146: 1003-1005, 2005.

TROSEID M, LAPPEGARD KT, MOLLNES TE, ARNESEN H, SELJEFLOT I: Changes in serum levels of E-selectin correlate to improved glycaemic control and reduced obesity in subjects with the metabolic syndrome. Scand $J$ Clin Lab Invest 65: 283-290, 2005.

TSAKADZE NL, SEN U, ZHAO Z, SITHU SD, ENGLISH WR, D'SOUZA SE: Signals mediating cleavage of intercellular adhesion molecule-1. Am J Physiol 287: C55-C63, 2004.

WEISBERG SP, MCCANN D, DESAI M, ROSENBAUM M, LEIBEL RL, FERRANTE AW, JR.: Obesity is associated with macrophage accumulation in adipose tissue. J Clin Invest 112: 1796-1808, 2003. 